\title{
Protected areas and community incentives in savannah ecosystems: a case study of Tanzania's Maasai Steppe
}

\author{
HAs SAN SACHEDin A and Fred NeLSON
}

\begin{abstract}
Two issues of central importance to conservation are developing an improved understanding of the relative roles of state protected areas and local institutions and developing effective strategies for creating communitybased incentives for conservation. We provide a case study of northern Tanzania's Maasai Steppe to explore these issues in the context of a savannah ecosystem where wildlife is mobile and depends extensively on community lands for seasonal habitats. We compare the impacts and outcomes of four approaches to developing local incentives for wildlife conservation on community lands: protected area benefitsharing, trophy hunting donations, village-private tourism concession contracts, and a direct payment scheme for habitat conservation. Tourism and direct payment concession areas have resulted in large areas of community land being protected for wildlife by villages as a result of the conditional and contractual nature of these ventures. By contrast, other approaches that provide economic benefits to communities but are not conditional on defined conservation actions at the local level demonstrate little impact on wildlife conservation on community lands. In spatially extensive ecosystems where protected areas cover limited areas and wildlife relies heavily on community and private lands, strategies based on maximizing the direct income of communities from wildlife are fundamental to the sustainability of such systems.
\end{abstract}

Keywords Community-based conservation, Maasai Steppe, protected areas, savannahs, Tanzania, wildlife

\section{Introduction}

central issue for global conservation is developing an A improved understanding of the appropriate roles and relative performance of state protected areas, on the one hand, and local or community-based resource management institutions on the other (Ostrom \& Nagendra, 2006). Whereas some contend that state protected areas are best

Hassan SACHEdinA* School of Geography and Environment, University of Oxford, Oxford, UK

Fred Nelson (Corresponding author) Maliasili Initiatives, P.O. Box 8372, Arusha, Tanzania. E-mail fnelson@habari.co.tz

${ }^{*}$ Current address: University of Kansas, Lawrence, USA

Received 18 April 2008. Revision requested 10 June 2008.

Accepted 30 January 2009. able to preserve biological resources (Bruner et al., 2001), other studies suggest that local communities may perform equally well in terms of sustaining resources such as forests (Hayes, 2006). The latter, community-based conservation, takes on a wide variety of forms ranging from passive participation to more active and direct local management of resources (Barrow \& Murphree, 2001). In this context we explore the search for effective conservation practices in northern Tanzania's Maasai Steppe, where large mammal populations move widely across a vast savannah landscape containing a mosaic of land uses and land tenure categories, including state protected areas and private lands held both individually and communally.

Our study reviews the impacts of four different approaches that attempt to use economic benefits to build local support and incentives for wildlife conservation in the Simanjiro plains, a key dispersal area for wildlife in the Maasai Steppe. These four strategies are: outreach and benefit-sharing efforts by Tarangire National Park authorities, contributions to local communities by trophy hunting concession holders, village-private tourism concession contracts, and a relatively new direct payment scheme. We evaluate and compare local benefits received through these four community-based strategies in terms of local actions and land-use decisions that affect the condition of wildlife habitats on village lands, specifically examining whether or not communities have taken measures to manage land for wildlife as a result of benefits received. We augment information on land-use decisions with data on local perceptions of two of the strategies, Park benefit-sharing and village tourism concessions, as a secondary indicator of impacts and outcomes.

\section{Study area}

The Maasai Steppe covers c. 35,000 $\mathrm{km}^{2}$ of north-central Tanzania (Fig. 1; Prins, 1987). The area is characterized by a semi-arid climate with spatially and temporally variable rainfall of $600-800 \mathrm{~mm}$ per annum but with high interannual oscillations and frequent droughts. For both wild and domestic herbivores these conditions result in variability in the distribution of water and forage, which leads to variable but regular annual migrations by wildlife as well as by local communities whose livelihoods are based on transhumant pastoralism. Large numbers of wild herbivores congregate around permanent water sources in Tarangire 


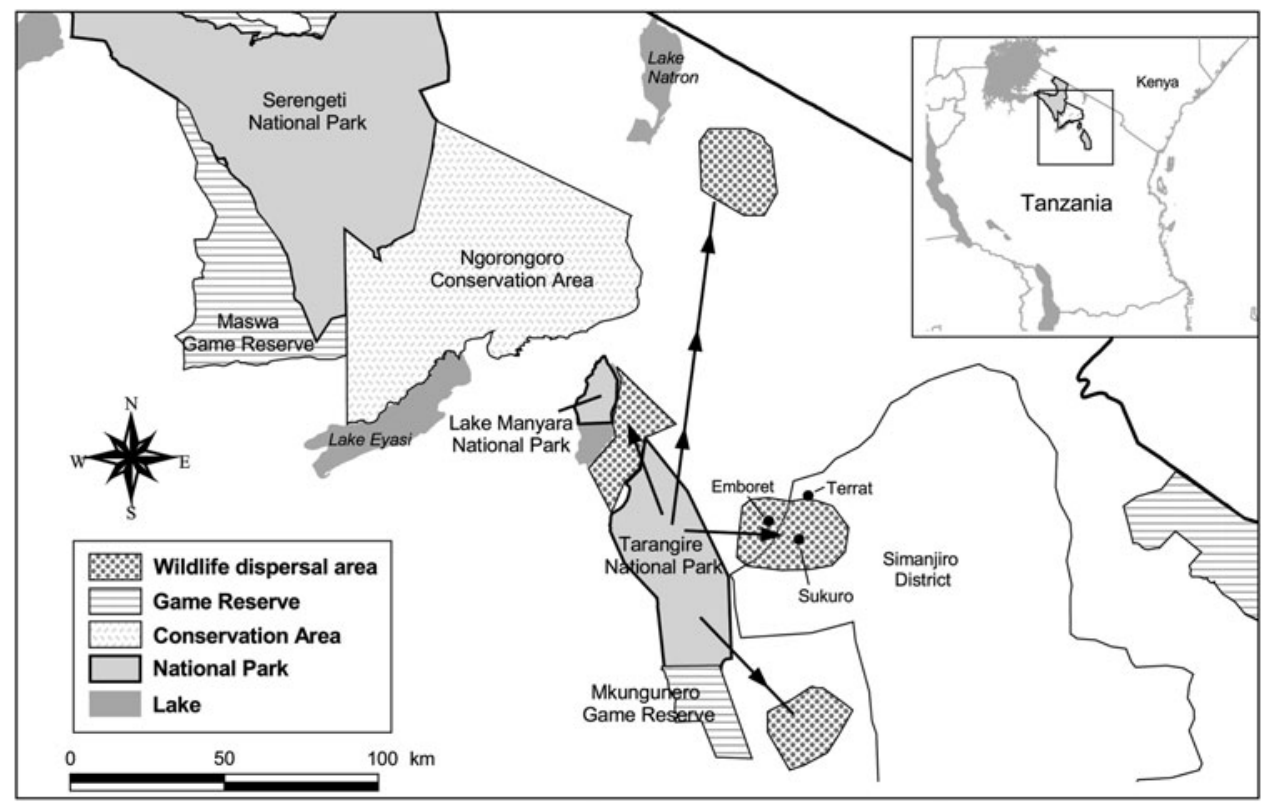

Fig. 1 Protected areas and wet season wildlife dispersal patterns from Tarangire National Park in the Maasai Steppe. Arrows indicate general migration routes to wet season ranges. Boundaries are approximate. Inset indicates the location of the main figure in Tanzania.

National Park during the dry season. During the rains (bimodal, with peaks in November and April), wildlife disperses to take advantage of the temporary availability of water and forage in other areas.

One of the main dispersal areas for wildlife during the rainy season is an expanse of short-grass plains in Simanjiro District, 25-40 km east of the Park. These plains are used by large numbers of wildebeest Connochaetes taurinus and zebra Equus quagga for grazing and calving. In the early 1970 s surveys estimated a wet season population of c. 10,000 wildebeest and 6,00o zebra (Kahurananga, 1981). Migration to these plains is driven not only by seasonal water availability but by high levels of phosphorus in the area's vegetation, as a result of underlying volcanic soils, and this is important for lactating female ungulates (Voeten, 1999).

Less than $15 \%$ of the Maasai Steppe is conserved in state protected areas. National parks are managed by a parastatal agency, Tanzania National Parks (TANAPA), which only allows activities related to wildlife conservation, scientific research, and non-consumptive tourism. The national parks of northern Tanzania are the lynchpin of the country's growing tourism industry. Revenue from fees at Tarangire National Park increased from c. USD 456,000 in 1992 to $>$ USD 2.1 million in 2005 (Fig. 2).

The key wet season dispersal areas and migration routes used by wildlife in the Maasai Steppe (Fig. 1) are within village lands falling under the jurisdiction of local pastoralist or agro-pastoral communities. The Simanjiro plains fall mostly within the boundaries of the villages of Emboreet, Sukuro and Terrat. These lands are managed by local Village Councils, which are elected bodies that manage customarily held lands on behalf of their constituent community. The ability of transhumant livestock management practices to co-exist with large populations of wild ungulates in East Africa is well-documented (Western, 1989; Homewood \& Rodgers, 1991).

Wildlife on village or private lands, as with animals in protected areas, is the property of the state. Wildlife outside national parks is managed primarily for tourist hunting, which is organized through a concession system managed by the Wildlife Division of the Ministry of Natural Resources and Tourism. This industry generates c. USD 12 million annually from hunting fees and at least twice that in overall economic production (Lindsey et al., 2007). In the Maasai Steppe nearly all village lands rich in wildlife are included within hunting concessions allocated by central government, and trophy hunting is the most economically important use of wildlife in Simanjiro District.

Aerial survey data covering a large part of the Maasai Steppe (centred on Tarangire National Park and the Simanjiro dispersal area) for 1988-2001 recorded declines of 46.7

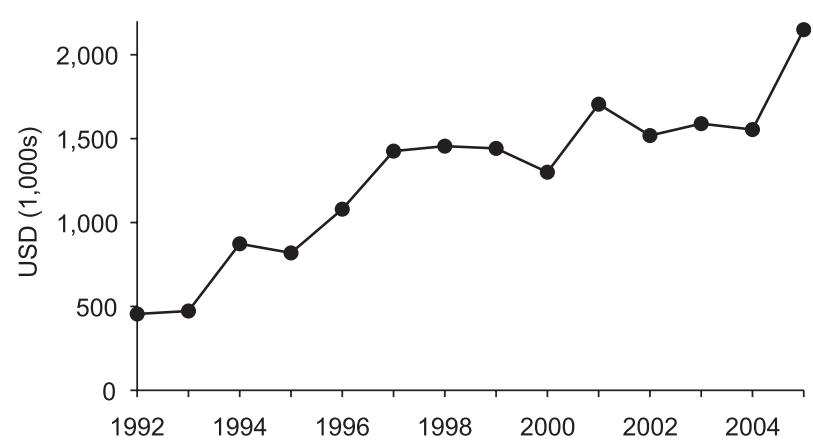

Fig. 2 Direct revenue generated by Tarangire National Park, 1992-2005 (from Sachedina, 2008). 
and $66.7 \%$ of large mammal species in dry and wet season counts, respectively (Stoner et al., 2007). The percentage of species increasing in dry season counts was zero and only elephants Loxodonta africana, which have recovered in Tanzania since the 1989 international ivory trade ban and accompanying improvements in local law enforcement, increased in wet season counts (Stoner et al., 2007; Foley \& Faust, 2010).

Wildlife declines in the Maasai Steppe are driven by widespread illegal hunting and the conversion of habitats from savannah rangelands to agricultural cultivation (Foley, 2004; Sachedina, 2008). Wildlife migration routes and dispersal areas have been progressively lost to spreading agriculture and settlements since the 1980 s (Borner, 1985). The livelihoods of pastoralist communities throughout Kenya and Tanzania have undergone significant changes as a result of internal and external forces, leading to an increasing reliance on agriculture as a livelihood option and resultant changes in land-use (Homewood et al., 2001; NortonGriffiths, 2007). In Emboreet village 93\% of households are engaged in farming, with acreage under cultivation increasing and expected to increase substantially in the near future, although the amount of land cultivated remains $<10 \%$ of the total (Sachedina, 2008).

Historic conservation measures in the Maasai Steppe, such as the creation of exclusive state protected areas and attempts to impose restrictions on farming and livestock numbers, have resulted in long-standing tensions between local community interests and conservation objectives (Igoe \& Brockington, 1999; Igoe, 2004). Thus conservation in the Maasai Steppe faces a paradox: the realities of land tenure patterns and wildlife habitat requirements renders local support and incentives essential for conserving wildlife but policies and practices have created antagonisms between those communities and formal conservation interests.

\section{Methods}

Our study draws on published and unpublished studies and data collected by Sachedina (2008) in Emboreet village, Simanjiro District, from July 2003 to June 2006. Data on revenues from tourism and hunting operators were recorded from the relevant companies, and data on benefitsharing from Tarangire National Park was obtained from Tanzania National Parks. Boundaries of village tourism concessions and areas set aside for conservation at the local level were mapped with a global positioning system and their areas calculated with the geographical information system ArcView v. 3.2 (ESRI, Redlands, USA).

Data on local perceptions of wildlife and tourism benefits were collected through a broad-scale survey of 226 households in Emboreet village, involving a range of information on socioeconomic activities and land tenure trends, and local perceptions of wildlife conservation and tourism activities. This survey comprised a questionnaire administered by HS and two Maasai research assistants from Emboreet village (Raymond Teekishe and Olterere Lemtunde) during 2003-2005. The survey was conducted in Kiswahili, or in Maa and translated into Kiswahili, and covered $55 \%$ of total village households and $65 \%$ of all homesteads (clusters of homes). This survey was followed up with a more detailed 12-month, repeat survey of 37 households during 2005-2006, with the households randomly selected from the total village household list. The repeat survey took place in three sub-villages of Emboreet to allow comparison on a north-south gradient along the Park boundary. Households were visited an average of 4.4 times each between March 2005 and February $2006(252$ total visits).

The broad-scale questionnaire collected qualitative and quantitative information on household income and expenditures and sought to understand the role of wildlife revenues in livelihood strategies. This questionnaire was administered to heads of households, in most cases men. The second survey captured seasonal variations in livelihoods and household dynamics and afforded an opportunity to cross-check data. This survey was administered to both men and women in each household. Men were asked about livestock dynamics, market data, and farm and offfarm incomes over a 2-month period; weekly expenditure data were collected for the preceding week for ease of recollection. Women were asked about daily livestock milk yields, as well as a 24-hour household food survey, about gifts given or received by the sub-household over the preceding month, and weekly market expenditure. Demography of the family and livestock herds were also tracked through each questionnaire.

Both surveys were based on a stratified wealth-ranking exercise (Brockington, 1998). In Tanzania the basic unit of administration is the village, which is divided into subvillages. Emboreet is divided into seven sub-villages. A full count was made of household heads in the village, drawn up by the sub-villages in a participatory manner because accurate government census records did not exist. As the economies and prosperity of households within the same boma (a collection of households within a single fenced enclosure), and economies of sub-households within the same household, can be different (White, 1980), households were ranked according to wealth class (wealthy, middling and poor). The household list formed the basis of a wealth ranking in each sub-village. After grouping households into wealth categories a random sample was selected within each category in proportion to the category's size. This process took place after the household list and wealth ranking was generated. The household list was used to select households randomly for inclusion in the broad-scale survey in all seven sub-villages. At the end of the broadscale survey the list was then used to select a random 
sample of households from three sub-villages for the second survey.

In addition to the two surveys, 127 semi-structured interviews were carried out with villagers, village leaders, district officers, NGO staff, farmers, tourism and hunting operators, tanzanite miners and government employees during 20022006. These interviews included questions about livestock, farming, and the politics surrounding conservation, land and village level governance. The dynamics of tanzanite mining and trophy hunting were also explored, all with the aim of developing a detailed ethnography of village livelihoods and responses towards conservation. Findings were triangulated through focal group discussions and using information gathered from key informants.

\section{Results}

\section{National Park outreach and benefit sharing}

Starting in the late 1980s Tarangire National Park began sharing a proportion of revenues with local communities to channel benefits to surrounding landholders and improve relations with these communities (Bergin, 2001). TANAPA formed a new unit, the Community Conservation Services, which works to improve communication between parks and surrounding communities. This includes providing financial support to local social development projects in an attempt to grant adjacent communities a stake in Park revenues. During 2000-2005 the Community Conservation Services contributed a total of USD 329,669 to community development projects in the six districts adjacent to the Park, including USD 152,353 to villages in Simanjiro District. For Emboreet village benefits received were USD 32,699 during this period, a mean of USD 6,540 per year. Three local development projects were funded with these revenues based on discussions between the village and the Community Conservation Services (Table 1).

In the first, broad-scale survey $48 \%$ of Emboreet villagers claimed that the village benefits from Tarangire National Park, compared to $33 \%$ who stated that the village does not benefit. However, there is no evidence of changes in local behaviour or land use as a result of receiving these benefits.

TABLE 1 TANAPA Community Conservation Service contributions to Emboreet village, 2000-2005.

\begin{tabular}{llll}
\hline Project & Financial year & Sector & USD \\
\hline $\begin{array}{l}\text { Construction of } \\
\text { dormitory }\end{array}$ & $2000-2001$ & Education & 12,261 \\
$\begin{array}{c}\text { Renovation of school } \\
\text { administration block }\end{array}$ & $2003-2004$ & Education & 15,438 \\
$\begin{array}{l}\text { Renovation of } \\
\text { cattle dip }\end{array}$ & $2004-2005$ & Livestock & 5,000 \\
\hline
\end{tabular}

Conflicts between Park authorities and villagers persist, and many communities in the Simanjiro area remain dubious or hostile to formal state conservation interests. Only $4 \%$ of Emboreet residents perceived their own household as benefiting from the Park. Land tenure conflicts are at the root of continued tensions between the Park and villages; $71 \%$ of Emboreet residents perceived the Park's boundary to have encroached onto community lands. These local views have behavioural implications. When asked if farms serve to block the expansion of the Park onto community lands $74 \%$ of Emboreet residents answered in the affirmative, compared to $18 \%$ in the negative. Thus the community supports the expansion of farms partly as a strategy to defend their land tenure from perceived protected area expansion.

\section{Trophy hunting contributions}

During 1997-2002 game fees collected from hunting in Simanjiro District averaged c. USD 250,000 per year (Kibebe, 2005). Villages do not receive any of this revenue directly, although hunting companies are legally required to provide support to village development in the areas where they hunt. District government receives $25 \%$ of game fees from hunting concessions in the district; these revenues are, nominally, supposed to be shared with the villages where hunting takes place, although this rarely happens (Baldus \& Cauldwell, 2004). In Emboreet direct village-level hunting contributions such as donations of money or items such as medical supplies or furniture, in kind and in cash, averaged USD 5,631 per year during 2001-2005.

Although such local contributions represent a significant annual income from wildlife, these donations are not made according to any contractual or conditional relationship between hunting companies and local communities. Benefits received by villages do not correspond or relate to specific actions taken to support conservation. Hunting companies base their operations on concessions granted by the Wildlife Division and do not attempt to negotiate land use or access agreements at the village level. Because hunting companies are licensed centrally with no requirements to negotiate directly at the local level, conflicts between trophy hunting and local livelihood activities such as livestock grazing sometimes occur. There are no instances in Simanjiro District of communities setting aside land for wildlife conservation as a result of income from trophy hunting.

\section{Community-based tourism ventures}

Starting in 1990 tour operators began to negotiate concession agreements with local communities in Simanjiro District for access to village lands adjacent to Tarangire National Park (Dorobo Tours \& Oliver's Camps Ltd, 1996). These contractual agreements provide for cash payments to the villages (based on daily per client fees coupled with set 
annual concession fees), in return for the villages setting aside a portion of their land for tourism and wildlife. Seasonal livestock grazing is explicitly allowed to continue in these concession areas according to customary grazing management rules. In Emboreet village initiation of these agreements had an immediate impact, as several thousand hectares of communal land near the Park that had been allocated by the village for division into individual farming plots was instead reserved for the tourism concession (D. Peterson, pers. comm.). Similar village-private tourism ventures have spread to other villages in the area following the emergence of these ventures in Emboreet.

The scale of revenues these ventures have been able to generate for communities has increased as Tanzania's tourism industry has grown. In 2005 Emboreet village earned $>$ USD 40,000 from these ventures, up from c. USD 2,000 in 1999 (Fig. 3). Tourism ventures in Emboreet village produce substantially more revenue than other sources of village income such as TANAPA benefit sharing and donations from hunting companies (Fig. 4).

Seventy-one percent of Emboreet residents reported that tourism benefits the village, although only $8 \%$ perceived tourism as benefiting their household. A significant problem in Emboreet is poor financial management and accountability but community support for tourism is widespread because the villagers view the tourism concessions, located directly adjacent to the Park, as helping to prevent appropriative expansion of the Park onto their land.

Emboreet's two tourism concession areas comprise 15,600 ha of village land set aside adjacent to Tarangire National Park (Fig. 5). These land-use designations are legally supported by village bylaws and a land-use plan that zones communal uses for grazing and tourism and individual uses for farms and settlements. To the north the villages of Lolkisale and Naitolya have additionally set aside c. 23,000 ha of land as tourism concessions in a similar contractual arrangement with other tourism companies.

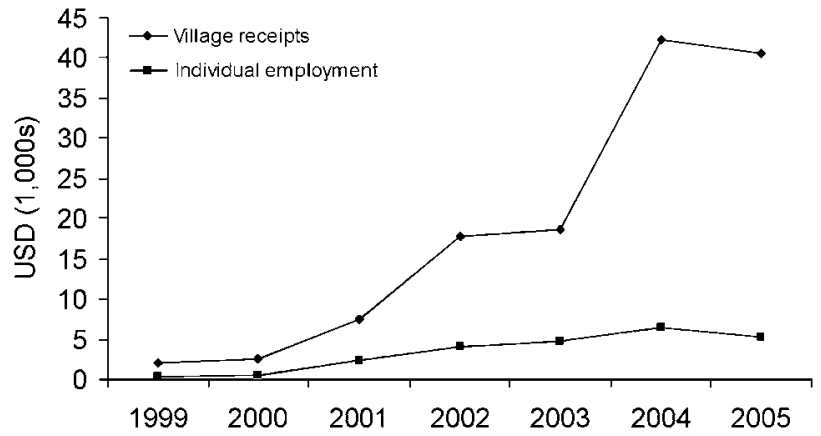

FIG. 3 Emboreet village revenue from tourism operators' annual concession and bed-night fees, and revenue from individual employment at tourism camps, 1999-2005 (from Sachedina, 2008).

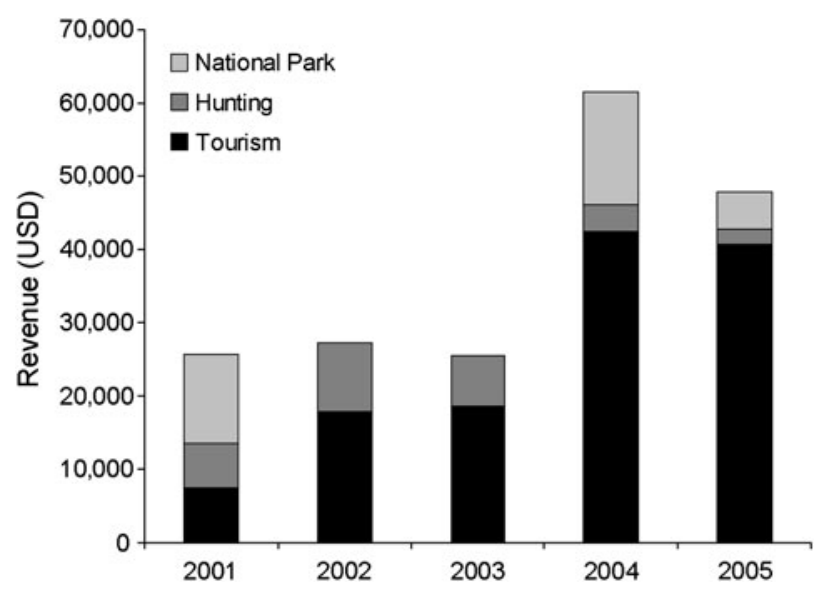

FIG. 4 Relative value of Tarangire National Park benefit-sharing programmes, voluntary contributions from hunting concession holders and village tourism ventures in Emboreet village, 20012005 (from Sachedina, 2008).

\section{Direct payments}

A new community-based conservation strategy currently being piloted in the Simanjiro plains involves making direct payments to local communities in return for land being protected for conservation by the village (Nelson et al., 2010). This initiative builds on the conceptual framework of direct payments for environmental services (Ferraro \& Kiss, 2002; Wunder, 2007) in an effort to develop an alternative mechanism for generating local economic incentives for wildlife conservation on community lands. A group of local tour operators has negotiated with Terrat village that, like Emboreet, contains about one-third of the short-grass Simanjiro plains, for the community's protection of 9,300 ha of key habitat (Fig. 5) in return for set guaranteed annual payments of c. USD 4,500 to the Village Council.

In this case, although no tourism is actually being carried out in the village, the payment is made solely based on the village providing habitat protection that is valued by the tour operators for the land's conservation value. The village provides a defined ecological service by agreeing not to farm or settle in the concession area but continues to use it as seasonal livestock pasture and is also obliged to try to prevent illegal wildlife use in the area. Although this initiative has only operated for c. 4 years it provides an important new, and potentially cost-effective, strategy for achieving conservation goals on community lands (Nelson et al., 2010).

\section{Discussion}

Several findings emerge from a comparison of the impacts of these four approaches to building community support and incentives for wildlife conservation in the Maasai Steppe. Community-private tourism agreements in three villages to the east of Tarangire National Park have resulted 


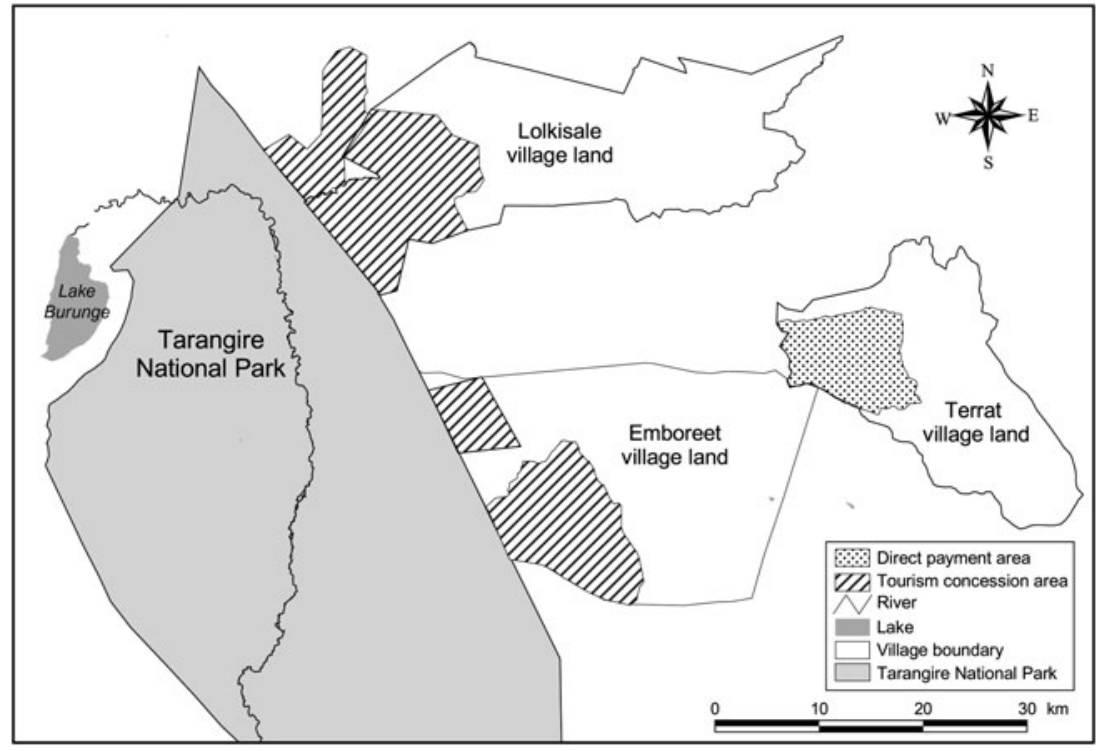

FIG. 5 Tourism concession and direct payment conservation areas adjacent to Tarangire National Park. All boundaries are approximate. in 38,600 ha being protected as tourism concessions, where wildlife is the primary form of land use. A novel direct payment agreement modelled on these tourism concessions has additionally led to Terrat village setting aside 9,300 ha for conservation. This total land area of 47,900 ha is equivalent to c. $18 \%$ of the size of Tarangire National Park, and therefore represents a major local contribution to the regional conservation estate.

Tourism concessions and the direct payment scheme are governed according to formal contracts with village councils, where mutual responsibilities are defined, and payments are conditional on conservation actions by the villages. Some of these arrangements have proven remarkably durable; Emboreet's contract with one tourism company has been in place, on a 5-year renewable basis, since 1991.

The main challenges these ventures have faced have been local governance issues and external conflicts. Poor accountability in the use of revenues by village councils is a problem, and may contribute to the low proportion of households reporting direct benefits accrued from tourism despite high overall revenues in Emboreet village. In addition, since c. 1999, there have been widespread conflicts between centrally-issued trophy hunting concessions and village-private tourism ventures (Nelson, 2004). These conflicts reflect divergent institutional interests; local communities capture revenue directly from tourism whereas hunting revenues flow to the state, and thus local and central bodies tend to promote different types of wildlifebased enterprises in these areas. These recurrent conflicts have been a constraint on the viability of community-level tourism ventures in Simanjiro and other parts of northern Tanzania.

Trophy hunting concessions in Simanjiro District contribute to village income from wildlife but there is no evidence of a link between these local benefits and local conservation actions or behaviours. No land has been set aside for wildlife as a result of village revenues from trophy hunting companies. In a context where wildlife depends heavily on community lands it is therefore unclear if trophy hunting's substantial revenues benefit landscape-scale conservation objectives in the Maasai Steppe (cf. Lindsey et al., 2007).

TANAPA's community development and outreach programme produces significant financial benefits for local communities but these have also not resulted in any documented local allocations of land to conservation purposes. This is largely because TANAPA's contributions, like those of trophy hunting companies, are not conditional on such local actions. They are not negotiated as conditional, contractual agreements but are implemented as ad hoc unconditional donations. These revenues therefore provide no direct link between wildlife benefits and local conservation actions, and do not create any demonstrable incentives for communal conservation measures.

An important influence on perceptions of the Park's community conservation efforts is that the provision of local economic benefits occurs alongside continued expansion of protected areas and resultant loss of community lands and resources. A new protected area to the south of Tarangire National Park, Mkungunero Game Reserve, was gazetted in 1996, creating new boundary conflicts and tension between protected area managers and local pastoralist communities (Masara, 2005). Emboreet villagers and the Park managers continue to experience conflicts over issues of livestock straying into the Park, the exact location of the contested boundary between village lands and the Park, and grievances resulting from damage to villagers' property by wildlife. Residents of Emboreet view loss of land to protected areas as a major threat to their livelihoods and an important reason to continue expanding farms to 
prevent the future loss of these areas to conservation interests.

In this way, continued pursuit of protectionist conservation strategies in a social and ecological context where wildlife depends on communal or private lands can be counter-productive, prompting local behavioural responses to Park expansion that undermine conservation objectives. Thus while Schwartzman et al. (2000) warn of 'perils in parks' in terms of pursuing strict protectionist approaches at the expense of political alliances with indigenous people in tropical forest environments, our findings go further in suggesting that it is the parks themselves that, at least in certain contexts, may be perilous. These potential negative impacts of protected areas on conservation objectives at the ecosystem scale should be considered in evaluations of the performance of state protected areas (Bruner et al., 2001; Hayes, 2006).

Although numerous studies have reviewed a range of diverse efforts to integrate conservation objectives with local livelihoods in Africa (Hulme \& Murphree, 2001), relatively few studies provide comparative assessments of the effectiveness of different types of community conservation efforts in a single locale. Our findings indicate that passive approaches based on benefit-sharing have had limited impact in generating community actions favourable to wildlife conservation in key areas in Simanjiro District outside Tarangire National Park. In contrast, efforts to develop community incentives for conservation through direct conditional payments made in exchange for land being set aside and protected by communities have had a more tangible impact. A key point to emphasize in comparing community-based approaches in this manner is the importance of local ecological context.

Many community conservation initiatives, including those of TANAPA, aim principally to improve local support for protected areas. Kangwana \& Ole Mako (2001) contended that TANAPA's benefit-sharing and outreach work has improved relations between Tarangire National Park management and surrounding communities. Similar findings with regards to improved attitudes towards parks on the part of local communities as a result of this TANAPA programme have been recorded in other ecosystems in Tanzania (Holmes, 2003). In Simanjiro, however, these initiatives may improve relations between park managers and local communities yet still have little or no significant impact on overall conservation outcomes at the ecosystem scale. This is because conservation in the Maasai Steppe is more reliant on community lands than it is on state protected areas; if community-park relations are improved but communities continue to lack direct incentives for conserving wildlife on their lands then the overall impact is likely to be minimal in the context of extensive savannah ecosystems with mobile wildlife populations.

In contrast, in protected areas where wildlife is not as mobile or as dependent on areas outside park boundaries, the objective of community conservation initiatives will be different. In the case of the small montane forest parks of south-western Uganda (Adams \& Infield, 2001), for example, outreach efforts may have a greater positive impact on park management and conservation outcomes merely by improving community-park relations. Furthermore, more strictly protectionist strategies that focus on enforcing park boundaries and policing resource uses in these relatively small areas surrounded by agricultural lands may be viable. But in extensive savannah ecosystems where mobile wildlife populations depend directly on habitats on private and communal lands, local economic incentives are essential and strictly protectionist approaches are not sustainable (Norton-Griffiths, 2007). The balance between protected areas and community-based approaches, and the types of strategies employed to develop local conservation incentives, need to be tailored to the ecological as well as the social context.

Sustaining mobile wildlife populations in extensive savannah ecosystems such as the Maasai Steppe, where land-use decisions and land tenure are inherently decentralized, requires developing direct local incentives for conservation based on negotiated relationships between wider conservation interests and local communities. Traditional, centralized management systems based primarily on state protected areas, regulation and law enforcement are insufficient to sustain such ecosystems (Western, 1989; Hutton \& Leader-Williams, 2003). There is a need to develop a deeper understanding of the costs and benefits of parks in such contexts. As our case study demonstrates, the continued expansion of state protected areas may actually serve to undermine the local support that conservation depends upon in such systems by perpetuating conflicts over land use and tenure and leading to behavioural responses by local people that are not supportive of ecosystem-scale conservation. Community-based conservation efforts should strive to develop direct incentives based on conditional negotiated agreements between private or public conservation interests and local communities. Strategies that focus primarily on economic benefits from wildlife without making those benefits conditional on local conservation performance demonstrate little impact. Similarly, outreach efforts that focus on improving relations between communities and protected areas are less relevant in areas such as the Maasai Steppe where the underlying issue is the land-use choices of communities that may live far from the protected areas. The most effective community-based interventions have been conditional and contractual agreements that exchange wildlifebased revenues for protection of land or wildlife by local communities. The relative effectiveness of protected areas and different types of community-based strategies are thus both strongly influenced by biophysical ecosystem characteristics, and managers should design their interventions 
according to such contextual factors. Our findings indicate a need to moderate or limit protected area expansion in extensive and heterogeneous ecosystems and to focus on community-based strategies that provide benefits in a conditional manner tied directly to local land-use choices and conservation actions.

\section{Acknowledgements}

Helen Newing, David Peterson, Charles Foley and two anonymous referees provided useful comments on earlier versions of this article. Lara Foley and Dave Williams provided data used for preparing the maps. HS is grateful to the Tanzania Commission for Science and Technology for permission to carry out field research in Emboreet, to Simanjiro District Council and Emboreet Village Council for numerous forms of local support in collecting data, and to Raymond Teekishe and Olterere Lemtunde for research assistance.

\section{References}

Adams, W.M. \& Infield, M. (2001) Park outreach and gorilla conservation, Mgahinga Gorilla National Park, Uganda. In African Wildlife and Livelihoods: The Promise and Performance of Community Conservation (eds D. Hulme \& M. Murphree), pp. 131-147. James Currey, Oxford, UK.

Baldus, R.D. \& Cauldwell, A.E. (2004) Tourist Hunting and its Role in Development of Wildlife Management Areas in Tanzania. In Proceedings of the 6th International Game Ranching Symposium, Paris (6-9 July). International Foundation for the Conservation of Wildlife, Paris, France.

Barrow, E. \& Murphree, M. (2001) Community conservation: from concept to practice. In African Wildlife and Livelihoods: The Promise and Performance of Community Conservation (eds D. Hulme \& M. Murphree), pp. 24-37. James Currey, Oxford, UK.

BERGIN, P. (2001) Accommodating new narratives in a conservation bureaucracy: TANAPA and community conservation. In African Wildlife and Livelihoods: The Promise and Performance of Community Conservation (eds D. Hulme \& M. Murphree), pp. 88-105. James Currey, Oxford, UK.

Borner, M. (1985) The increasing isolation of Tarangire National Park. Oryx, 19, 91-96.

Brockington, D. (1998) Land loss and livelihoods: the effects of eviction on pastoralists moved from the Mkomazi Game Reserve, Tanzania. PhD thesis, University College London, London, UK.

Bruner, A.G., Gullison, R.E., Rice, R.E. \& da Fonseca, G.A. (2001) Effectiveness of parks in protecting tropical biodiversity. Science, 291, 125-128.

Ferraro, P.J. \& Kiss, A. (2002) Direct payments to conserve biodiversity. Science, 298, 1718-1719.

Foley, C. (2004) What is the future of Tarangire National Park? Miombo, 27, 12-14.

Foley, C.A.H. \& FAUST, L.J. (2010) Rapid population growth in an elephant Loxodonta africana population recovering from poaching in Tarangire National Park, Tanzania. Oryx, 44, 205-212.

Hayes, T.M. (2006) Parks, people, and forest protection: an institutional assessment of the effectiveness of protected areas. World Development, 34, 2064-2075.
Holmes, C.M. (2003) The influence of protected area outreach on conservation attitudes and resource use patterns: a case study from western Tanzania. Oryx, 37, 305-315.

Homewood, K.M., Lambin, E.F., Coast, E., Kariuki, A., KiKula, I., Kivelia, J. et al. (2001) Long-term changes in Serengeti-Mara wildebeest and land cover: pastoralism, population, or policies? Proceedings of the National Academy of Sciences of the USA, 98, 12544-12549.

Homewood, K.M. \& Rodgers, W.A. (1991) Maasailand Ecology: Pastoralist Development and Wildlife Conservation in Ngorongoro, Tanzania. Cambridge University Press, Cambridge, UK.

Hulme, D. \& Murphree, M. (2001) African Wildlife and Livelihoods: The Promise and Performance of Community Conservation. James Currey, Oxford, UK.

Hutton, J.M. \& Leader-Williams, N. (2003) Sustainable use and incentive-driven conservation: realigning human and conservation interests. Oryx, 37, 215-226.

Igoe, J. (2004) Conservation and Globalization: A Study of National Parks and Indigenous Communities from East Africa to South Dakota. Wadsworth/Thomson Learning, Belmont, USA.

Igoe, J. \& Brockington, D. (1999) Pastoral Land Tenure and Community Conservation: A Case Study from North-east Tanzania. International Institute for Environment and Development, London, UK.

Kahurananga, J. (1981) Population estimates, densities and biomass of large herbivores in Simanjiro Plains, northern Tanzania. African Journal of Ecology, 19, 225-238.

Kangwana, K. \& Ole Mako, R. (2001) Conservation, livelihoods, and the intrinsic value of wildlife: Tarangire National Park, Tanzania. In African Wildlife and Livelihoods: The Promise and Performance of Community Conservation (eds D. Hulme \& M. Murphree), pp. 148-159. James Currey, Oxford, UK.

Kiвеве, J. (2005) Socio-economic and ecological impacts of safari hunting and commercial farming on key stakeholders, Simanjiro District, Tanzania. MSc thesis, Norwegian University of Life Sciences, Aas, Norway.

Lindsey, P.A., Roulet, P.A. \& Romañach, S.S. (2007) Economic and conservation significance of the trophy hunting industry in sub-Saharan Africa. Biological Conservation, 134, 455-469.

Masara, Y. (2005) Wildlife Areas Expansion and Local Land Rights: The Case of Kimotorok Village, Simanjiro District. Unpublished Report. Pastoralists Indigenous Non-Governmental Organizations Forum, Arusha, Tanzania.

Nelson, F. (2004) The Evolution and Impacts of Community-Based Ecotourism in Northern Tanzania. Drylands Issue Paper no. 131. International Institute for Environment and Development, London, UK.

Nelson, F., Foley, C., Foley, L.S., Leposo, A., Loure, E., Peterson, D. et al. (2010) Payments for ecosystem services as a framework for community-based conservation in northern Tanzania. Conservation Biology, 24, 78-85.

Norton-Griffiths, M. (2007) How many wildebeest do you need? World Economics, 8, 41-64.

Ostrom, E. \& Nagendra, H. (2006) Insights on linking forests, trees, and people from the air, on the ground, and in the laboratory. Proceedings of the National Academy of Sciences of the USA, 103, 19224-19231.

Prins, H.H.T. (1987) Nature conservation as an integral part of optimal land use in East Africa: the case of the Masai Ecosystem of northern Tanzania. Biological Conservation, 40, 141-161.

SACHEDINA, H. (2008) Wildlife is our oil: conservation, livelihoods and NGOs in the Tarangire Ecosystem, Tanzania. PhD thesis, University of Oxford, Oxford, UK. 
Schwartzman, S., Moreira, A. \& Nepstad, D. (2000) Rethinking tropical forest conservation: perils in parks. Conservation Biology, 14, 1351-1357.

Stoner, C., Caro, T., Mduma, S., Mlingwa, C., Sabuni, G., Borner, M. \& SChelten, C. (2007) Changes in large herbivore populations across large areas of Tanzania. African Journal of Ecology, 45, 202-215.

TANAPA (Tanzania National Parks) (2002) Tarangire National Park-General Management Plan/Environmental Impact Assessment. Tanzania National Parks, Arusha, Tanzania.

Voeten, M.M. (1999) Living with wildlife: coexistence of wildlife and livestock in an East African savannah system. $\mathrm{PhD}$ thesis, Wageningen University, Wageningen, The Netherlands.

WESTERN, D. (1989) Conservation without parks: wildlife in the rural landscape. In Conservation for the Twenty-first Century (eds D. Western \& M. Pearl), pp. 158-165. Oxford University Press, Oxford, UK.

White, B.N.F. (1980) Rural household studies in anthropological perspective. In Rural Household Studies in Asia (eds H.P. Binswanger, R.E. Evenson, C.A. Florencio \& B.N.F. White), pp. 13-25. Singapore University Press, Singapore.
W Under, S. (2007) The efficiency of payments for environmental services in tropical conservation. Conservation Biology, 21, 48-58.

\section{Biographical sketches}

HASSAN SACHEDINA is a consultant in environment and development, specializing in sustainable rural livelihoods and natural resources management. Born in Kenya, he has worked as a Senior Program Officer for the African Wildlife Foundation in Kenya and Tanzania, as well as with the International Gorilla Conservation Programme, the Laikipia Wildlife Forum and the Selous Rhino Trust. Fred Nelson has worked on community-based natural resource management, ecotourism, and conservation policy in eastern Africa since 1998. During 2000-2005 he was Tanzania programme director for the Sand County Foundation Community Based Conservation Network, working with a number of pastoralist communities in northern Tanzania and helping to establish the Tanzania Natural Resource Forum. He currently works as an independent consultant on conservation and rural development issues. 